\title{
Multicultural Education of Local Culture and National Perception
}

\author{
Budiono \\ University of Muhammadiyah Malang \\ budiono_fkipumm@yahoo.co.id
}

\begin{abstract}
Multiculturalism is seen as an ideology that emphasizes cultural diversity in equality or egalitarianism. The diversity creates superior andinferior, majority and minority, and dominance and non-dominance, so all parties must put the citizen's equality as the main thing. The difference between the basic concepts of multiculturalism and plural societies is that the existence of a plural society occurs naturally (given), while the multicultural society is seen as the result of a cultural process that develops as an ideology. The structure of plural society is characterized by two basic characteristics which are in horizontal and vertical perspective. Horizontally, it is characterized by the reality of social unity based on ethnic differences, religion, customs, and regional differences, while vertically, the structure of Indonesian society is characterized by the sharp differences between the top layer and the underlay. The difference in the basic concept of multiculturalism and pluralism remains rooted in the local culture of Indonesian society that supports the spirit of nationalism with the motto 'Bhinneka Tunggal Ika'. The shared values and history of the nation's journey provide a great spirit to maintain solidarity and social unity.
\end{abstract}

Keywords: Multiculturalism, Pluralism, Local Culture, National Identity and National Perception

\section{INTRODUCTION}

Studying the structure of Indonesian society is broadly understood by two basic features. First, horizontal feature which is marked by the reality of social unity based on ethnic differences, religion, customs, and regional differences. Second, vertical feature or the structure of Indonesian society which is characterized by sharp vertical differences between the top layer and the underlay [9]. These differences grow and develop naturally which can be understood from several perspectives, both sociologically and anthropologically as well as other approaches that will enrich the perception to comprehend the structure of Indonesian society as a whole.

Furthermore, J.S Furnivall [13] reveals that plural societies in concept can be identified into four categories as follows:

Compound society with a balanced competition means a plural society consisting of communities or ethnics have a more or less balanced competitive power.Plural society with a balanced competition is characterized by the absence of a dominant tribe so that there is a harmonious and stable inter-ethnic cooperation in the community. Such conditions can be exemplified in the Javanese and Sundanese tribes where the two tribes can be mutually cooperative and no one dominates each other.
A plural society with a dominant majority means a plural society of ethnic communities with unbalanced competitive strength. It means there is a greater competitive power than any other group's competitive power. Plural society with a dominant majority is characterized by a large tribe and has a dominant influence on other smaller tribes. The dominance is usually seen in the political and economic dominance of other smaller ethnic groups.

A plural society with a dominant minority means there is an ethnic minority group in this community life, but they have a wide competitive advantage so that their competitive power dominates certain areas of life such as politics and economics. In real terms, such a category society occurred in the Dutch East Indies colonial era that controlled the people of Indonesia, so the indigenous people became third-class citizens after the European and Foreign Eastern (Chinese).

A plural society with fragmentation means community life composed of a number of ethnic groups, but they are all in small numbers so that no single group dominates. Community conditions are usually prone to conflict because each ethnic group has a balanced influence, but it has the potential for social consolidation as well.

Cliford Geertz [3] defines the pluralistic society of Indonesia as a fragmented society into a more or less independent sub-system, in which each subsystem bounds in primordial bonds. The reality of the plural society of Indonesia conveyed by the two experts (Furnivall and Cliford Geertz) is indeed a necessity that must be accepted. Indonesian people must recognize and understand that this plurality is the gift of God, not the human's form factor [7]. After the independence of Indonesia along with the development of Indonesian civilization, there should be an explanation to complement the discussion of the diversity of Indonesia in order to strengthen national integration. There are several factors that influence the creation of multicultural society in Indonesia as proposed by Nasikun [9] which are as follows:

Geographical factor; as Indonesia is the largest archipelagic country in the world. It consists of more than 17.000 islands extending between $95^{\circ}-141^{\circ}$ East Longitude, and $6^{0}$ North Latitude - $11^{\circ}$ South Latitude, which greatly influence the formation of this nation's pluralism. A vast archipelago of tropical regions which have different natural potentials has different characteristics for its inhabitants.

The climate/weather and soil structure differences; because the width of each island is different, they have 
different climate and soil structure. As a result, this difference affects the pattern of people's livelihood as well as patterns of behavior.

Location; Indonesia is located between two oceans (the Indian Ocean and the Pacific Ocean) and two continents (Australia and Asia), which is the cross position of the world where the influx of cultural influences from outside the archipelago is more open. The influences of Hinduism, Buddhism, Islam, Catholicism, Protestantism, and Confucianism along with the speed of the trade world of that time, as evidence that these religions come from outside the archipelago, have a great influence on the occurrence of cultural pluralism and religion in this country.

The migration of the Indo-China ancestors in 2000s $\mathrm{BC}$ anthropologically; this geographical setting forced them to settle in isolation. The advancement of information and transportation that is still very simple affects geographical isolation as well as different natural conditions resulting in the growing and developing population according to their respective conditions. This is what makes the growth and development of ethnicity in Indonesia as mentioned [3].More than 300 ethnic groups live in Indonesia, as a country of pluralism.

\section{METHOD}

This research used qualitative approach. According to [2], qualitative approach is a process of research and understanding based on a methodology used to investigate a social phenomenon and human problems.

The social phenomena studied in this article are multicultural education, local culture, and national perception in high schools (SMA) in Malang. Data collection techniques used in this study were: (1) observation, (2) interviews, and (3) document analysis. In its implementation, the initial activity is compiling the instrument to collect data for the three techniques in order to capture data from the research subject that has been set. In details, the three techniques of data collection are described as follows:

\section{Observation}

Observation technique was intended to obtain data on the implementation of scouting in SMA Negeri 1 Malang, SMA Negeri 7 Malang, and SMA Negeri 8 Malang, which included description of the condition of groups, groups' work program, groups' program implementation, and groups' program evaluation, until the achievements were achieved by groups. Observations were made in scouting activities, both indoor and outdoor.

Interview

Interviews were conducted to obtain data on the implementation of scouting education based on local culture in the context of multicultural education. Informants in this study were the Principal, Vice Principal of Student Affairs, Scout Coach, and scout members.

\section{Document Analysis}

Document analysis aimed to collect data in the form of documents about scouting. The documents included scouting guidebooks, scouting curriculum, scout pocketbook (general skill requirements), matrix and scouting program schedule, and documentation of scouting activities of the three high schools.

The researcher used qualitative research to collect and analyze data in which he acted directly as a human instrument. Even though the data analysis was narrative, the researcher did the data reduction, present data, and verified data. The data were presented narratively related to the theme that was formulated and arranged based on the structure designed for the focus of the research. The data analysis was in line with the formulated interactive model [8], conducted in several phases, such as data reduction, data presentation, and conclusion.

\section{RESULT}

The concept of a multicultural society is actually relatively new. Around the 1970s, the multicultural movement first appeared in Canada, followed by the United States, Australia, Britain, Germany and others [7]. The concept of multiculturalism here is not the same as the concept of ethnic or cultural diversity that characterizes plural societies as proposed by Furnivall. The concept of plural society is the interpretation of diversity that has been given by the nature not a human form factor, while the concept of multicultural society defines the state of society in which there are cultural diversity, language, religion, customs, and patterns as a behavioral structure of community members that functions as a guide for life. In the context of nationbuilding, the term multicultural has formed an ideology called multiculturalism [13]. Starting from this understanding, it is clear that the concept of multicultural is the result of a human thought that interprets diversity as an ideology, in contrast to the concept of a plural society that views diversity as a relation that is not human nature.

Starting from the reality of the plurality of Indonesian philosophy, there has been an attempt to bind the diversity in the motto of Bhinneka Tunggal Ika which means diversity in integrity, an effort to unite the pluralism in Indonesia. In the context of the nation-state, the motto is synonymous with the view of multiculturalism where the effort of the national integration process is on human effort, not solely because of natural formation. Since post-reformation accompanied by the release of the policy of regional autonomy, it is suspected that there has been a decline in the spirit of nationalism, especially among young generations. According to [15], the weakening of the spirit of nationalism or the perception of our nationality is caused by several problems: (1) low human resource coexistence, (2) the nation's militant approaches the critical point, (3) Indonesian identity that has been faded, and (4) the strength of primordial or the spirit of regionalism. To overcome these problems, we should not rule out the strength and threat of the national disintegration, which affects the integrity and sovereignty of the Republic of Indonesia. 
Strategies to address the challenges that threaten the integration of the nation need to be pursued by various strategic measures, such as: (1) improving leadership quality, (2) revitalizing/re-actualizing nationalism, (3) increasing national militancy, and (4) affirming national identity in accordance with the noble values of the nation. Furthermore, what needs to be done is to reaffirm and re-actualize the cultural values of the nation which are believed to increase the spirit of nationalism, and neutralize the cultural values that are less supportive of the spirit of nationalism. The attempts to explore the values of local culture that support the spirit of nationalism must be done to maintain a pluralistic nation, but it still supports national integration.

\section{CONCLUSION}

Multiculturalism as an ideology which emphasizes cultural diversity in equality or egalitarianism. The diversity that creates superior and inferior, majority and minority, and dominance and non-dominance, no longer plays a role in the context of nation-building. The ideology of multiculturalism cannot be separated from the problems that support the ideology, namely politics and democracy, justice and law enforcement, employment and business opportunities, human rights, communal rights and minority groups, and ethical and moral principles. All parties should place the equality of the citizens as the main thing, the minority group that was originally a second-class citizen in the social structure should be transformed into a multicultural society in equality. The equalization of minority rights is based on the ideology of multiculturalism, in which the rights of the different groups of society must be recognized and valued in equality. Multiculturalism as an ideology is not a refusal of difference because multiculturalism is born out of diversity aimed at equality in nation-building. A multicultural nation needs a social unity derived from shared values. The common values and history of the nation's growth provide a spirit that helps to maintain solidarity and social unity. Solidarity and common goals are essential to perpetuate social unity in a multi-ethnic nation, and it can be done by accommodating shared values raised into national identity.

\section{REFERENCES}

[1] Arifin, Akhmad Hidayatullah al. Implementasi Pendidikan Multikultural dalam Praksis Pendidikan di Indonesia. Jurnal Pembangunan Pendidikan: Fondasi dan Aplikasi. Volume 1, Nomor 1, Juni, 2012

[2] Creswell, John.W. Qualitatif Inquiry and Research Design: Sage Publications, Inc 1998.

[3] Geertz, Clifford. Agama Jawa: Abangan, Santri, PriyayiDalam Kebudayaan Jawa. Bandung: Komunitas Bambu 2013.

[4] Kaelan. Negara Pancasila, Kultural, Historis, Filosofis dan Aktualisasinya.Yogyakarta: Paradigma 2013.

[5] Koentjaraningrat. Pengantar Ilmu Antropologi. Jakarta: Rineka Cipta 2002.

[6] Kymlicka, Will. Kewarganegaran Multikulural. Jakarta: LP3ES 2011.

[7] Mahfud, Choirul. Pendidikan Multikultural. Yogyakarta: Pustaka Pelajar 2013.

[8] Miles, Matthew B \&Huberman, A Michael. Qualitatif Data Analysis, Second Edition. London: Sage Publications 1994.

[9] Nasikun. Sistem Sosial Indonesia. Jakarta: Rajawali, 1988.

[10] Ritzer, George. Teori Sosiologi, Dari Sosiologi Klasik Sampai Perkembangan Terkahir Postmodern. Yogyakarta: Pustaka Pelajar, 2012.

[11] Rosyada. Dede Pendidikan Multikulturaldi Indonesia Sebuah Pandangan Konsepsional Jakarta. Sosio Didaktika: Vol. 1, no. 1 Mei 2014

[12] Sukardi, Tanto. 2014. Mencari Format Baru Pendidikan Berbasis Multikultural di Indonesia.SosioDidaktika: Vol. 1, no. 1 Mei 2014

[13] Setiadi, Elly M. Dan Usman Kolip. Pengantar Sosiologi, Pemahaman Faktadan Gejala Permasalahan Sosial: Teori, Aplikasi dan Pemecahannya. Jakarta: Prenada Media Group 2011.

[14] Syaifuddin, Achmad Fedyani, Membumikan Multikulturalismedi Indonesia.Etnovisi. Jurnal Antropologi Sosial Budaya Vol. II No. 1 april 2006 ISSN: 0216-843x 2006.

[15] Tukiran. 2014 Pendidikan Multikulturaldan Naasionalisme Indonesia. Sosio Didaktika: Vol. 1, no. 1 Mei 2014 